\title{
The Silurian of southwestern margin of the East European Platform (Ukraine, Moldova and Romania): lithofacies and palaeoenvironments
}

\author{
Natalia RADKOVETS ${ }^{1, *}$ \\ 1 Institute of Geology and Geochemistry of Combustible Minerals of the NAS of Ukraine, Naukova 3a, 79060 Lviv, Ukraine
}

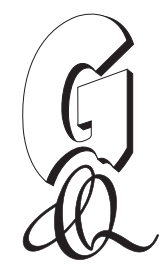

Radkovets, N., 2015. The Silurian of southwestern margin of the East European Platform (Ukraine, Moldova and Romania): lithofacies and palaeoenvironments. Geological Quarterly, 59 (1): 105-118, doi: 10.7306/gq.1211

\begin{abstract}
Silurian strata, stretching along the western margin of the East European Platform from the Baltic to the Black Sea, represent a potential target for both conventional and unconventional hydrocarbon exploration. Distribution of the black shale facies, prospective for shale gas, and the reef facies, prospective for oil, has been studied in respect of palaeoenvironments. The Silurian sequence has been investigated in the territory of Ukraine (Volyn-Podillyan Plate, Dobrogean Foredeep) and correlated with the data on Moldova and Romania (Moldovian Platform). The occurrence of Silurian strata, their thickness, and petrographic and lithological characteristics allowed reconstructing the distribution of open-shelf, reef and lagoonal facies. The reef facies migrated during the Wenlock-Middle Pridoli, shifting towards the open sea and back towards the shore, and therefore has been termed a migrating reef facies. Correspondingly, the boundary between the open-shelf and reef facies was shifting. The facies distribution was controlled by the transgressive-regressive cycles, which caused the fluctuations of the shelf water depth in different time intervals of the Silurian. The shelf water depth of about $100 \mathrm{~m}$, where the top of the oxygen-minimum layer impinged on the sea bottom, was the boundary between the open-shelf facies, represented by organic-rich sediments, and the reef buildups.
\end{abstract}

Key words: East European Platform, Silurian, lithofacies, reef, Baltica shelf, palaeoenvironments.

\section{INTRODUCTION}

Silurian sequence of the East European Platform currently attracts much interest, being one of the main European potential targets for shale gas exploration. It covers a great area, stretching from the Baltic to the Black Sea. The Silurian within the Ukrainian territory, which is the principal subject of this study, is the continuation of the Polish part of the sedimentary basin, whose shale gas potential has been widely discussed (e.g., Poprawa, 2010; Sachsenhofer and Koltun, 2011). Facies distribution within the Silurian sequence of the East European Platform is of great importance for oil and gas prospecting. Location of the reef and open-shelf facies in the study area allows delineating the occurrence of two separate potential plays. The external border of the reef, which, as it is shown below, was migrating during the Silurian, marked the occurrence of organicrich facies of graptolitic shales. The latter occupied the extensive area in the deeper part of the basin. These shales are prospective for shale gas all over the territory of their occurrence (Poprawa, 2010; Sachsenhofer and Koltun, 2012). Therefore, it is important to understand the nature and to delineate the boundary between these facies. The limestones, forming the reefal buildups, are the potential oil-reservoir rocks. Numerous

\section{*E-mail: radkov_n@ukr.net}

Received: September 3, 2014; accepted: January 7, 2015; first published online: January 14, 2015 oil shows have been observed in boreholes at Lokachi, Gorokhiv and Oglyadiv prospects within the Ukrainian part of the East European Platform (Rizun et al., 2007).

Investigations of the Silurian strata in Ukraine were based on the analysis of data from existing boreholes, in particular well-log data, core samples, and thin sections. The content of $\mathrm{CaCO}_{3}$ in rocks was calculated from chemical analyses performed at the Institute of Geology and Geochemistry of Combustible Minerals. Thin sections were examined under a polarizing microscope. Well-log data along with the data of analytical and petrographic analyses of rocks were used for lithostratigraphical correlation of the examined sections. Lithological sections allowed composing a map of Silurian occurrence with isopachs and facies distribution. Correlation of the data on western Ukraine with adjacent areas of Silurian occurrence, involving those from Moldova and Romania (Lodan, 1999; Olaru et al., 2006; Olaru and Țabără, 2011; Tari et al., 2014) as well as Poland, Lithuania, Latvia and Estonia (Nestor and Einasto, 1977; Einasto et al., 1986; Lazauskiene, 2003; Porębska et al., 2004; Zdanaviciute and Lazauskiene, 2007; Verniers et al., 2008; Poprawa and Kiersnowski, 2008; Skompski et al., 2008; Łuczyński et al., 2009; Poprawa, 2010; Kaljo et al., 2012; Tari et al., 2012; Podhalańska, 2013; Porębski et al., 2013; Jarochowska and Kozłowski, 2014) allowed elucidating the occurrence of these strata, their thickness and petrographic composition over the vast territory within the southwestern margin of the East European Platform, and obtaining the integral characteristics of depositional environments in the Silurian of the study area. This was a base for palaeoceanographic reconstruction and elucidation of different types of sediments and facies distribution within the southern palaeoshelf of Baltica. 
The objective of this study is to show the occurrence of the main Silurian lithofacies in the study area, describe the palaeoenvironments and the nature of these deposits prospective for oil and gas, which explain the regularities of their distribution both in time and space.

\section{GEOLOGICAL BACKGROUND}

The study area is the southwestern margin of the East European Platform. It includes the following tectonic units: VolynPodillyan Plate, Moldovian Platform and Dobrogean Foredeep (Fig. 1). The sedimentary cover of this territory rests on an Archean-Proterozoic basement made up of magmatic and metamorphic rocks. The basement crops out at the surface within the Ukrainian Shield and monoclinally dips westward towards the Teisseyre-Tornquist Zone. The maximum thickness of sedimentary cover reaches $10 \mathrm{~km}$ in the Volyn-Podillyan Plate and $7 \mathrm{~km}$ in the Dobrogean Foredeep (Kruglov and Tsypko, 1988; Chebanenko et al., 1990). The sedimentary succession is represented by Neo-Proterozoic (Riphean and Vendian strata), Paleozoic (Cambrian, Ordovician, Silurian, Devonian and Carboniferous deposits in the Volyn-Podillyan Plate, Moldovian Platform and Dobrogean Foredeep; Permian deposits in the Dobrogean Foredeep), Mesozoic (Triassic deposits in the Dobrogean Foredeep, Jurassic and Cretaceous deposits in the Volyn-Podillyan Plate, Moldovian Platform and Dobrogean Foredeep) and Cenozoic (Paleogene, Neogene and Quaternary deposits).

At the beginning of the Silurian, the entire southwestern margin of the East European Platform was uplifted and underwent intense denudation. As a result, the Silurian deposits rest upon the eroded surface made up of Ordovician, Cambrian and Vendian rocks (Chebanenko et al., 1990; Gerasimov et al., 2006).

Silurian strata stretch along the southwestern margin of the East European Platform from the Baltic to the Black Sea. Thickness of the Silurian regularly increases from the Ukrainian Shield westwards towards the Teisseyre-Tornquist Zone, reaching the maximum values of over $1400 \mathrm{~m}$. Cross-sections I-I1 (Fig. 2) and II-II1 (Fig. 3) (see Fig. 1 for location) show the entire sedimentary cover of the study area, in particular the occurrence of the Silurian.

Within the southwestern margin of the East European Platform the Silurian system is represented by the Lower and Upper Silurian. It was established that the Lower Silurian platform strata of Poland and Lithuania comprise Llandovery and Wenlock (Verniers et al., 2008). As to completeness of the Lower Silurian stratigraphic succession at the territory of Ukraine there are different opinions. Krandiyevsky et al. (1968), Tsegelnyuk et al. (1983) and Drygant (2000) stated that the Lower Silurian is represented here with both Llandovery and Wenlock. Nikiforova et al. (1972) expressed doubts as to the presence of Llandovery in the Silurian sequence and assumed that these Lower Silurian strata should be considered as Wenlock. Rizun et al. (2007) concluded that within the territory of Ukraine the Lower Silurian platform strata are represented only by Wenlock (Kytayhorod and Bagovytsya stages). Upper Silurian covers the entire time range and includes Malynivtsy stage of Ludlow and Skala stage of Pridoli (Fig. 4).

\section{LITHOFACIES OF THE SILURIAN}

Silurian strata of the study area consist of carbonate, claycarbonate and clay deposits. In the Volyn-Podillyan Plate, they are subdivided into three facies: lagoonal, reef, and open shelf, occurring west of the Ukrainian Shield towards the Teisseyre-Tornquist Zone. The previous studies (Chyzh, 1977; Yushkevych et al., 1982; Drygant, 2000; Rizun et al., 2007; Kurovets et al., 2012) showed the boundaries of the reef facies in the Volyn-Podillyan Plate in the Wenlock (Bagovytsya stage), Ludlow (Malynivtsi stage) and Pridoli (Skala stage) in a different way.

The Silurian lithofacies map (Fig. 5) was constructed on the basis of our investigations from the Volyn-Podillyan Plate and Dobrogean Foredeep using the information contained in the above mentioned publications, which were compared with the data from Romania and Moldova (Kruglov and Tsypko, 1988; Lodan, 1999; Olaru et al., 2006; Olaru and Tabără, 2011; Tari et al., 2014). The map shows the occurrence of Silurian strata, their thickness and facies within the area from the border of Ukraine with Poland and Belarus to the Black Sea. Silurian sediments continuously cover the entire area, apart from separating bands where they are lacking. At monoclinal dipping, the thickness of Silurian strata increases gradually up to $700 \mathrm{~m}$ and then more sharply from 800 to over $1400 \mathrm{~m}$. The growth of thickness shows a clear dependence on the Silurian facies zoning. The quick thickness increase (800-1400 m) correlates well with the deeper-water open-shelf facies, while the thinner sequence reflects the shallow water reef and lagoonal facies.

\section{PETROGRAPHIC CHARACTERISTICS}

Lagoonal facies is represented (Nikiforova et al., 1972) by marlstones $(39-60 \%$ of biodetrital calcite, $34-48 \%$ of clay material and $4-11 \%$ of dolomite), biodetrital dolomitized limestones $(50-60 \%$ of calcite, $25-40 \%$ of dolomite and $10-15 \%$ of insoluble residue, mostly clay material) and gypsum and anhydrite-bearing dolomites, which occur in the eastern littoral part of the area. Gypsum and anhydrite in dolomites occur as veins and streaks of variable thickness (from $1 \mathrm{~mm}$ to $1 \mathrm{~m}$ ). Fossils are lacking. Westward, gypsum- and anhydrite-bearing dolomites pass laterally into dolomites, marls and dolomitized biodetrital limestones. Dolomites contain $69-75 \%$ of dolomite and $10-25 \%$ of clay material, admixture of dispersed calcite and small amount of silt (Fig. 6). The rock comprises the clay-carbonate matrix. Dolomite crystals $(0.1-0.5 \mathrm{~mm})$ are usually rhombohedral in shape. Small solitary calcite crystals are observed too.

Rhombohedral dolomite grains in clay-carbonate matrix of dolomite from the Sarata- 6 borehole, depth interval 4467-4470 m.

Reef facies, which represents the reef buildups between the two facies zones - lagoonal and open sea, is made up of limestones (biolithites according to Folk, 1962) as well as by biodetrital limestones and dolomites. Biolithites form the reef core surrounded from both sides by biodetrital limestones and dolomites. Biolithites are light grey, cream-grey and grey and consist of corals, crinoids, stromatoporoids and algae along with ostracods, gastropods and brachiopods. Chemical analysis shows that the $\mathrm{CaCO}_{3}$ content in the limestones mainly ranges between 80 and $90 \%$, reaching $98 \%$. Biodetrital limestones are represented by rounded and non-rounded biolithite debris with clay matrix. Biodetrital dolomites are fine-grained, macro- and micro-cavernous, fractured, completely recrystallized, full of debris of corals, crinoids, stromatoporoids, and contain stylolitic sutures.

Open shelf facies is represented by clay-carbonate-siliceous rocks often enriched with dispersed organic matter. Argillites are dark grey to black, unevenly limy, pyritized, and with solitary graptolites. Marlstones are grey to black, clayey, mainly detrital and granular. Fabric is cryptocrystalline, con- 


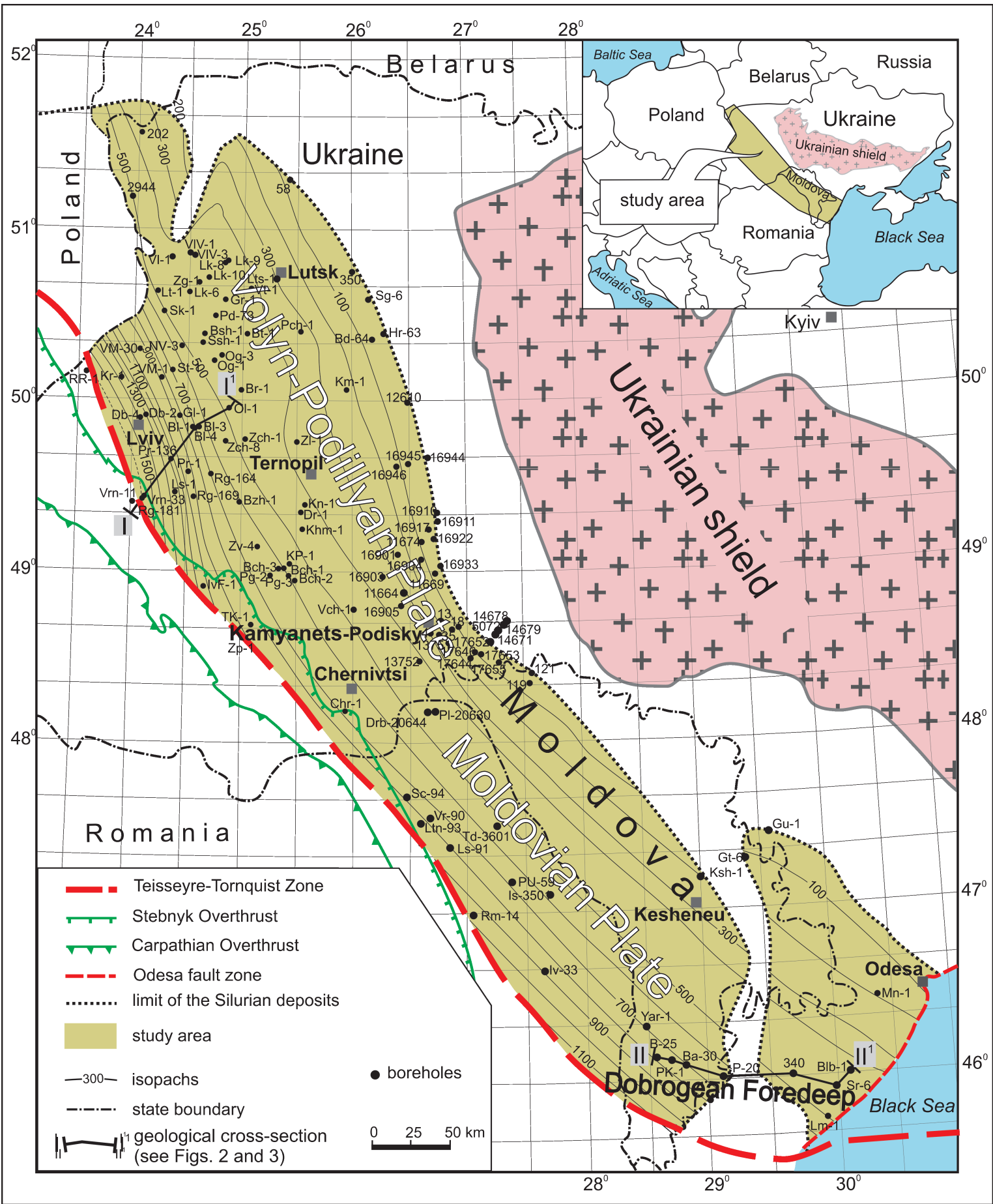

Fig. 1. Location map of the general distribution and thickness of the Silurian in the southwestern margin of the East European Platform

Boreholes: B - Baymaklia, Ba - Baurchi, Bch - Buchach, Bd - Brydok, BI - Baluchyn, Blb - Balabanivka, Br - Brody, Bsh Byshiv, Bt - Berestechko, Bzh - Berezhany, Chr - Chernivtsi, Db - Dublyany, Dr - Darakhiv, Drb - Darabani, Gl - Glynyany, $\mathrm{Gr}$ - Gorokhiv, Gt - Gyrtop, Gu - Gulanka, Hr - Horiv, IvF - Ivano-Frankivsk, Iv - Ivanesti, Is - Iasi, Khm - Khmelivka, Km Kremenets, Kn - Konopkivka, KP - Koropets-Pyshkivtsi, Kr - Krekhiv, Ksh - Kesheneu, Lk - Lokachi, Lm - Lyman, Ls Lishchyny, Lt - Litovezh, Ltn - Liteni, Lts - Lutsk, Mn - Myrne, NV - Novy Vytkiv, Og - Oglyadiv, Ol - Olesko, P Valya-Perzhey, Pch - Povcha, Pd - Pidberezzya, Pg - Pidgaytsi, PK - Kangaz, PI - Paltinis, Pr - Peremyshlyany, PU Popesti-Ungheni, Rg - Rogatyn, Rm - Roman, RR - Rava-Ruska, Sc - Suceava, Sg - Sergiyivka, Sk - Sokal, Sr - Sarata, Ssh - Sushne, St - Stremin, Td - Todireni, TK - Tlumach-Kolomya, Vch - Verkhniakivtsi, VI - Volodymyrivka, VIV Volodymyr-Volynsky, VM - Velyki Mosty, Vr - Vorona, Vt - Voyutyn, Yar - Yargara, Zch - Zolochiv, Zg - Zagoriv, ZI Zalozhtsi, Zp - Zagaypil, Zv - Zavadivka 


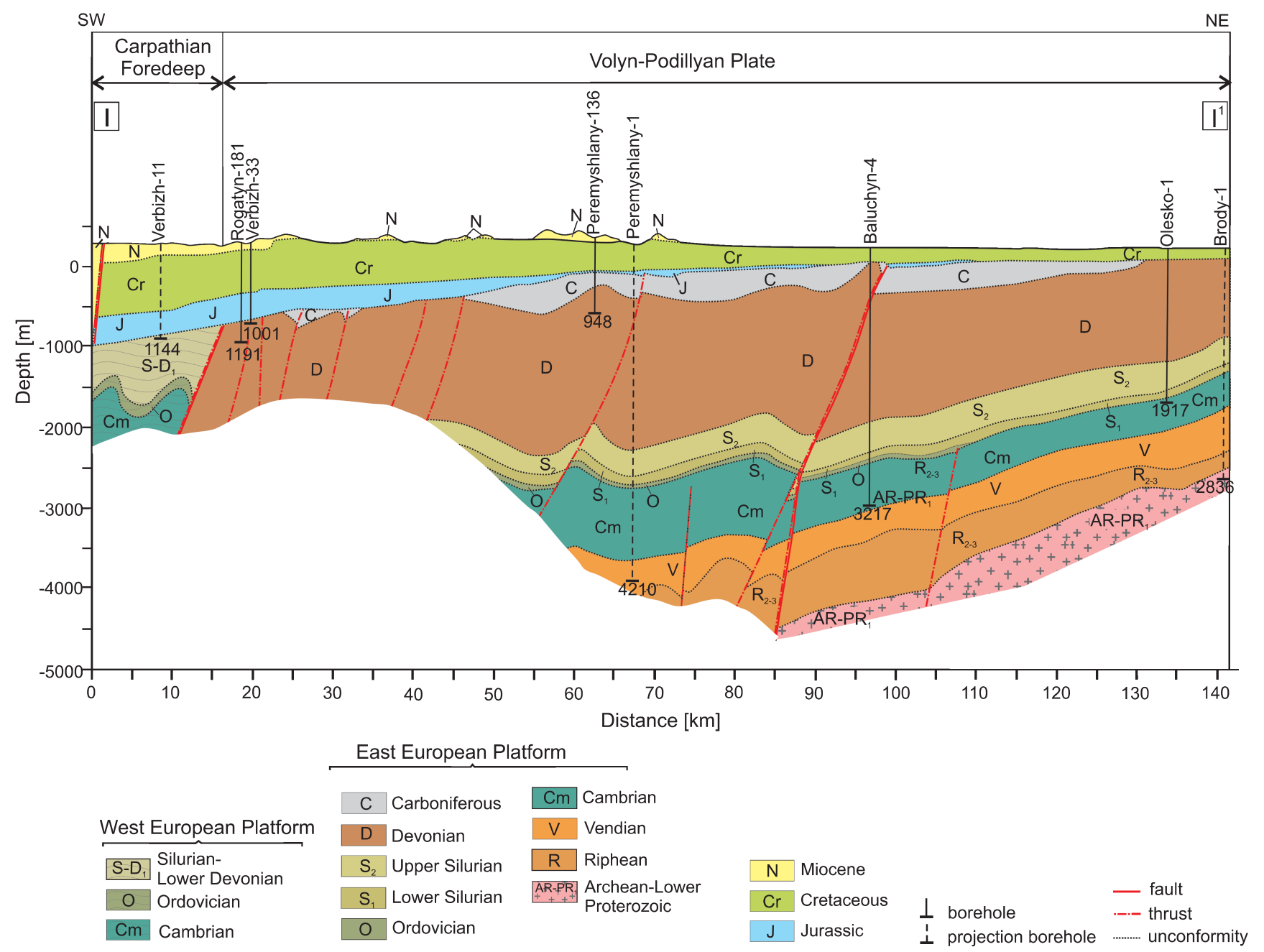

Fig. 2. Geological cross-section I-I through the Carpathian Foredeep and Volyn-Podillyan Plate (modified after Vashchenko et al., 2007)

See Figure 1 for location

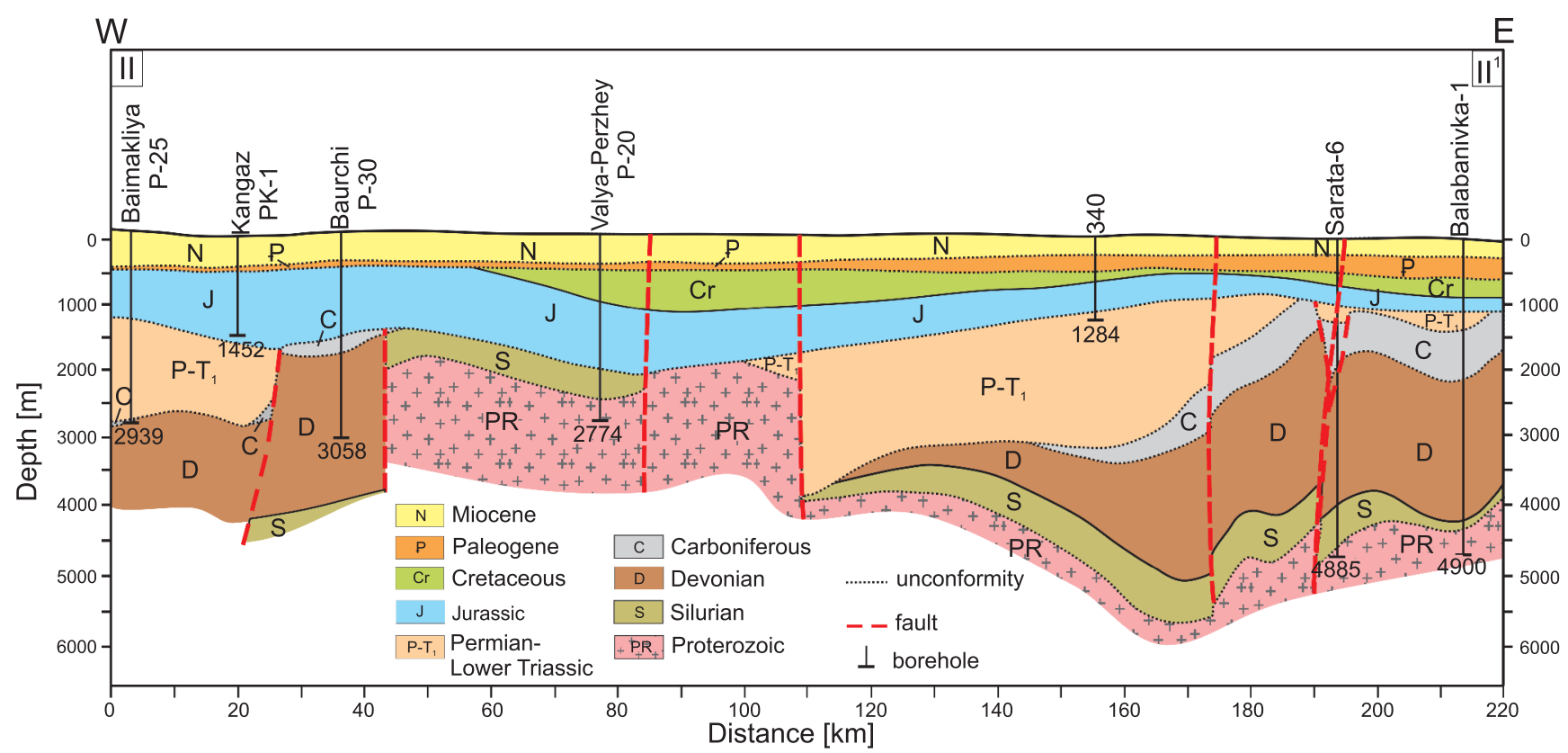

Fig. 3. Geological cross-section II-II ${ }^{1}$ through the Dobrogean Foredeep (modified after Gnidets et al., 2007) 


\begin{tabular}{|c|c|c|c|c|c|c|c|c|c|c|c|}
\hline \multicolumn{4}{|c|}{ Nikiforova et al. (1972) } & \multicolumn{4}{|c|}{ Drygant (2000) } & \multicolumn{4}{|c|}{ Rizun et al. (2007) } \\
\hline \multicolumn{2}{|c|}{ System } & \multirow{2}{*}{$\begin{array}{c}\text { Series } \\
\text { above } \\
\text { L_uddow_ow_- }\end{array}$} & \multirow{2}{*}{$\begin{array}{l}\text { Stage } \\
\text { Skala }\end{array}$} & \multicolumn{2}{|c|}{ System } & \multirow{2}{*}{$\begin{array}{c}\text { Series } \\
\text { Pridoli }\end{array}$} & \multirow{2}{*}{$\begin{array}{c}\text { Stage } \\
\text { Skala }\end{array}$} & \multicolumn{2}{|c|}{ System } & \multirow{2}{*}{$\begin{array}{c}\text { Series } \\
\text { Pridoli }\end{array}$} & \multirow{2}{*}{$\begin{array}{l}\text { Stage } \\
\text { Skala }\end{array}$} \\
\hline \multirow{5}{*}{$\frac{\frac{c}{\sqrt[D]{U}}}{\frac{D}{\bar{D}}}$} & & & & \multirow{6}{*}{$\frac{\frac{c}{\sqrt[T]{0}}}{\frac{\partial}{\bar{\omega}}}$} & \multirow{3}{*}{$\begin{array}{l}\frac{1}{1} \\
\frac{0}{2} \\
\frac{2}{2}\end{array}$} & & & \multirow{5}{*}{ 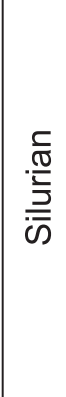 } & \multirow{3}{*}{$\begin{array}{l}\frac{1}{0} \\
\frac{0}{0} \\
\frac{0}{2}\end{array}$} & & \\
\hline & กำ & \multirow[t]{2}{*}{ Ludlow } & \multirow[t]{2}{*}{ Malynivtsi } & & & \multirow[t]{2}{*}{ Ludlow } & Malynivtsi & & & \multirow[t]{2}{*}{ Ludlow } & \multirow[t]{2}{*}{ Malynivtsi } \\
\hline & & & & & & & Bagovytsya & & & & \\
\hline & \multirow{2}{*}{$\sum_{0}^{1}$} & Wenlock & $\begin{array}{l}\text { Ustya } \\
\text { Muksha }\end{array}$ & & \multirow{3}{*}{$\varliminf_{0}^{1}$} & \multirow[b]{2}{*}{ Wenlock } & \multirow{3}{*}{ Kytayhorod } & & \multirow{2}{*}{$\sum_{1}^{\grave{1}}$} & \multirow[b]{2}{*}{ Wenlock } & Bagovytsya \\
\hline & & $\begin{array}{c}\text { Upper } \\
\text { andovery } \\
?\end{array}$ & Kytayhorod & & & & & & & & Kytayhorod \\
\hline & & & & & & Landovery & & & & & \\
\hline
\end{tabular}

Fig. 4. Stratigraphic scheme of the Silurian deposits of the Volyn-Podillyan Plate (modified after Nikiforova et al., 1972; Drygant, 2000; Rizun et al., 2007)

glomerate-like and clumpy (Kurovets et al., 2010). The thickness of argillites significantly exceeds the thickness of coeval clay-carbonate rocks.

It has been established that the reef facies was changing its extent in various time intervals of the Silurian (Wenlock-Middle Pridoli), moving towards the continent or towards the open sea depending on transgressive-regressive cycles. Therefore, we term it as a migrating reef facies. Figure 6 shows the change of reef facies extent in time. In the Wenlock (Bagovytsya stage) the reef facies occupied a small area, in the Ludlow (Malynivts stage) the extent of this facies reached its maximum, while in the Pridoli (Skala stage) the area of the reef facies somewhat reduced comparing to the Ludlow. Correspondingly, the open shelf facies in these time intervals changed its external boundary. It occupied the maximum area in the Wenlock (Bagovytsya stage), the minimum one in the Ludlow (Malynivtsi stage) and an intermediate in the Pridoli (Skala stage).

Argillites are calcareous (carbonate content 10-40\%), siliceous (silica content $10-20 \%$ ), locally silty (up to $15-35 \%$ of silt), pyritized, laminated, dense and hard. The rocks are black in colour due to dispersed organic matter. Total organic carbon content usually ranges from 0.2 to $1 \%$, locally exceeding $2 \%$. Great thickness and type II kerogen allow considering these rocks to be a potential target for shale gas exploration. Figure $7 A$ and $B$ show the photomicrographs of limy argillite. Matrix of the rock is made up of fine mica scales and sub-parallel streaks of organic matter. Small amount of silt-size quartz grains, carbonates (calcite, dolomite) as well as muscovite scales is observed. Locally, there occur lenticular accumulations of silt-size quartz grains and relicts of calcareous bioclasts.

Marlstones (Fig. 7C, D) are dark grey, clayey, pyritized and dolomitized. The carbonate content is $43-54 \%$. The rock is finely and micro-laminated due to distribution of small pyrite grains, lenticular accumulations of organic matter and problematic calcareous bioclast debris. Marlstones consist of dispersed fine-scaly clay-carbonate particles, which form the matrix. Admixture of $0.01-0.08 \mathrm{~mm}$ size quartz grains is present in small amount. Abundant fine pyrite, often forming wavy microstreaks, is observed. Problematic calcareous bioclast debris, $0.1-0.8 \mathrm{~mm}$, occasionally $>1 \mathrm{~mm}$ in size, and possibly strongly recrystallised bioclasts are locally present.

Throughout the Silurian sequence there are numerous 0.05-3.0 m thick intercalations of K-bentonites (tuffites) (Fig. 8). For the basic section of Podillya, K-bentonites are shown after
Nikiforova et al. (1972). For the remaining sections they are indicated based on petrographic investigations, well-logs analysis and correlation with the basic section of Podillya. The SEM, X-ray and thermal analyses (Nikiforova et al., 1972) show that the clay material of these rocks is represented by glauconite-type hydromica, and their fibers envelop the relicts of volcanic ash particles. Along with the clay minerals, occurs mainly pyroclastic material represented by idiomorphic quartz grains, replaced by feldspars and ore minerals, and numerous biotite scales with diffused edges. K-bentonites are typical of the Upper Silurian. In particular, they are most abundant in the Malynivtsi stage (Ludlow), less in the Skala stage (Pridoli). In the Lower Silurian (Wenlock) two K-bentonite horizons are identified in the Peremyshlyany-1 and Lyman- 1 boreholes, and only one in other boreholes.

Huff et al. (2000) have interpreted the Ludlow and Pridoli K-bentonites of the Dnister Basin in Podillya as representing active volcanic arcs along the margin of the Rheic Ocean. Histon et al. (2007) showed that the ancient explosive volcanism in the form of altered airfall volcanic ash beds (K-bentonites) has the global occurrence in the Silurian succession, being reported in Europe, North America and Argentina. K-bentonite beds have been recognized in the Ordovician-Silurian transition (Ashgill-Early Llandovery) in the Yangtze Block, South China (Su et al., 2004).

\section{DISTRIBUTION OF LITHOFACIES}

Figure 8 shows the location of Silurian lithological sections, which give the best insight into the lithological features of these strata and spatial distribution of lithofacies. Separation of stages at lithological sections is based on the analysis of well-log data, K-bentonite beds occurrence, and petrographic investigations. The Podillya section (Nikiforova et al., 1972) was used for correlation of these boreholes, as it was constructed on the basis of investigation of 40 Silurian outcrops along the Dnister River and its tributaries. The data on these outcrops are especially valuable because presently most of them are submerged as a result of the Dnister hydroelectric power station construction 40 years ago.

Among the existing schemes of sea level reconstruction for the Silurian (e.g., Johnson, 1996, 2010; Azmy et al., 1998; Haq and Schutter, 2008; Olaru and Țabără, 2011; Fig. 9), we have 


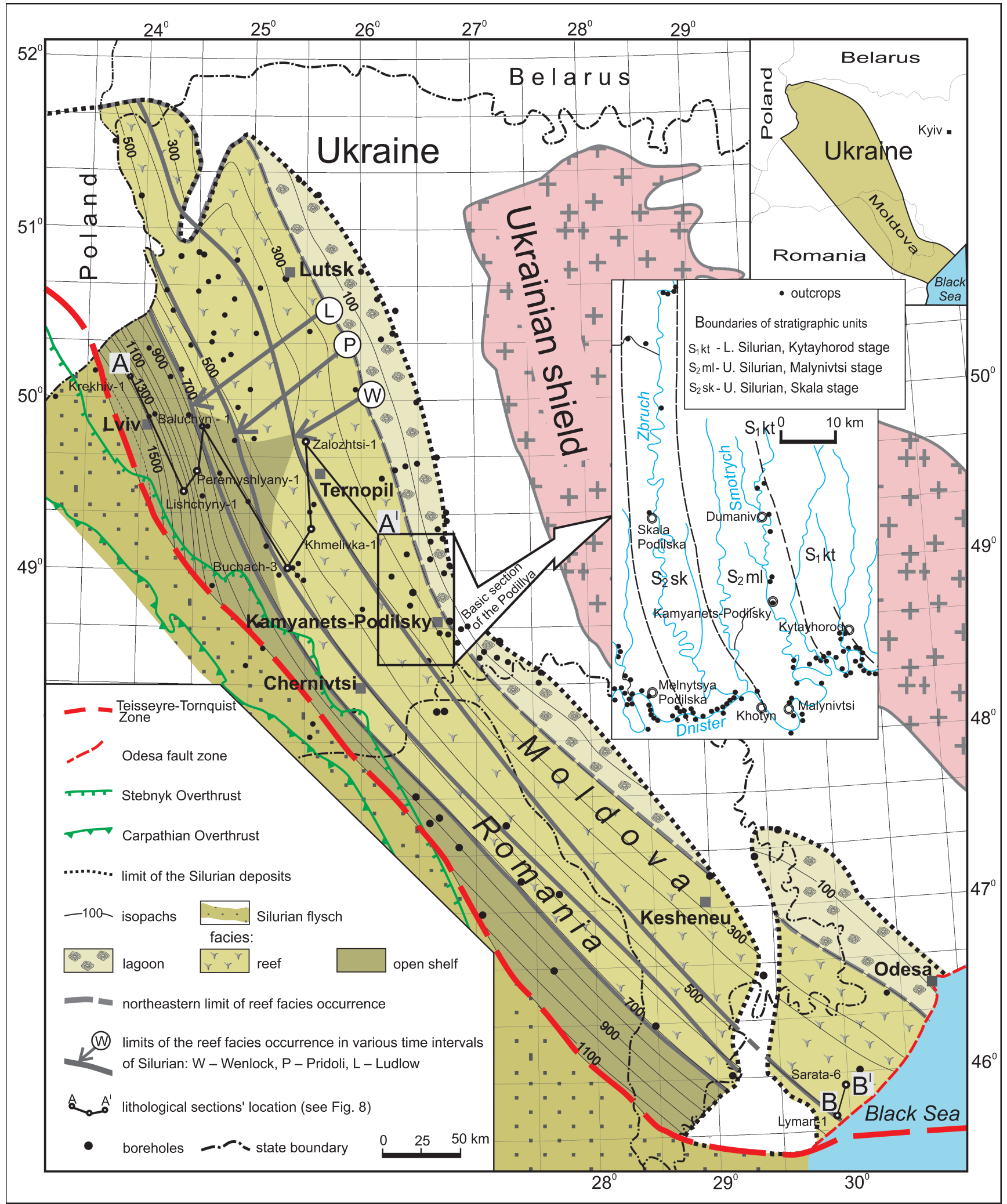

Fig. 5. Lithofacies map of the Silurian deposits in the southwestern margin of the East European Platform

used the regional scheme by Olaru and Tabără (2011) as the most appropriate one, as it has been constructed for the Volyn-Podillyan Plate. Lithological sections of the Volyn-Podillyan Plate and Dobrogean Foredeep (Fig. 8) reflect the influence of transgressive-regressive cycles on formation of petrographic composition of rocks. Lithological sections of the Krekhiv-1,
Lishchyny -1 and Peremyshlyany-1 boreholes (Volyn-Podillyan Plate) consist of clay and clay-carbonate organic-rich rocks typical for open shelf facies. From the Krekhiv-1 borehole westwards to Peremyshlyany-1, some changes in lithology are observed. Along with argillites and limy argillites, more marlstones and clayey limestones appear, showing the transition from 


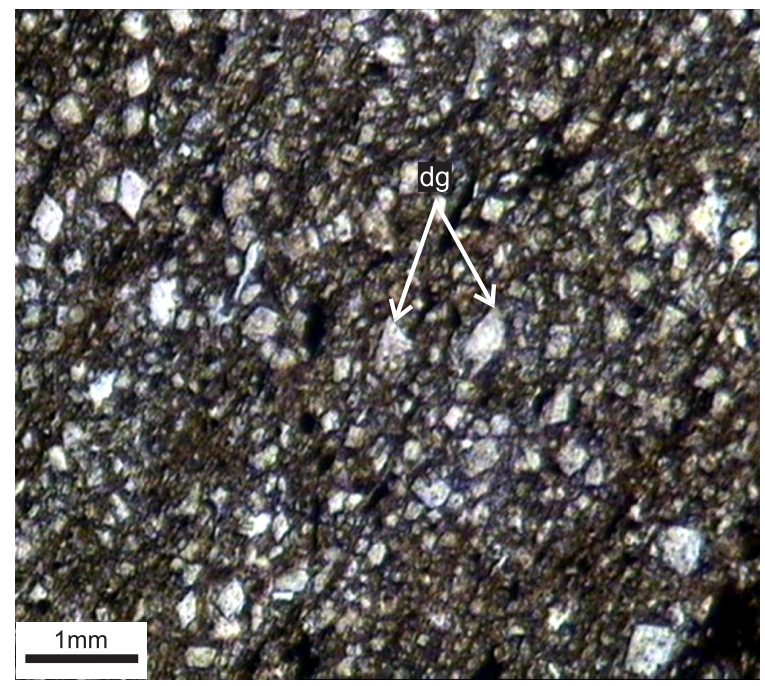

Fig. 6. Photomicrograph of a Silurian rock of lagoonal facies (Dobrogean Foredeep)

$$
\mathrm{dg} \text { - dolomite grains }
$$

more deep-water clay to shallower carbonate facies. The sections of Baluchyn-1, Buchach-3, Khmelivka-1 and Zalozhtsi-1 boreholes, and the key outcrop sections of Podillya are made up of clay-carbonate and carbonate rocks (marlstones, dolomites, biodetrital limestones). All the studied sections include thick (up to $60 \mathrm{~m}$ ) reef limestones of various age (Wenlock, Lud- low, Pridoli). Lithological observations and well-log data on Silurian strata in a number of boreholes from the Dobrogean Foredeep indicate similar clay-carbonate and carbonate rocks, in particular reef limestones containing up to $98 \% \mathrm{CaCO}_{3}$ (Fig. 10). Silurian lithological sections in the Lyman-1 and Sarata-6 boreholes, typical of the Dobrogean Foredeep, show their good correlation with the Zalozhtsi-1 borehole and the base outcrop sections in the Volyn-Podillyan Plate. Analysis of the lithological sections from the Dobrogean Foredeep shows that the spatial and temporal extent of all types of Silurian rocks perfectly correlates with the rocks from the Volyn-Podillyan Plate.

The formation of Silurian reefs in the southern shelf of Baltica started in the Wenlock (Nikiforova et al., 1972; Mõtusa and Grytsenko, 2007; Verniers et al., 2008; Olaru and Țabără, 2011). Figure 8 shows that a significant transgression took place during the Wenlock (Bagovytsya stage), which caused the shift of coastline further onto the continent towards the Ukrainian Shield. This palaeoceanographic event correlates well with the trend of reef construction. The Bagovytsya stage reef limestones are observed close to the palaeoshore (Fig. 8) in the basic section of Podillya. In the Ludlow, a significant regression took place. Lithological sections between the Baluchyn-1 and Zalozhtsi-1 boreholes (Fig. 8) show thick reef limestones $(25-60 \mathrm{~m})$ whose seaward boundary was located at the maximum distance from the shore. The Ludlow and Pridoli reef limestones of significant thickness $(25-50 \mathrm{~m})$ are also encountered in the Lyman-1 and Sarata- 6 boreholes in the Dobrogean Foredeep (Fig. 8). A considerable transgression with short-term regression cycles took place in the study area in the Pridoli. Lithological sections (Fig. 8) of the Buchach-1, Khmelivka-1
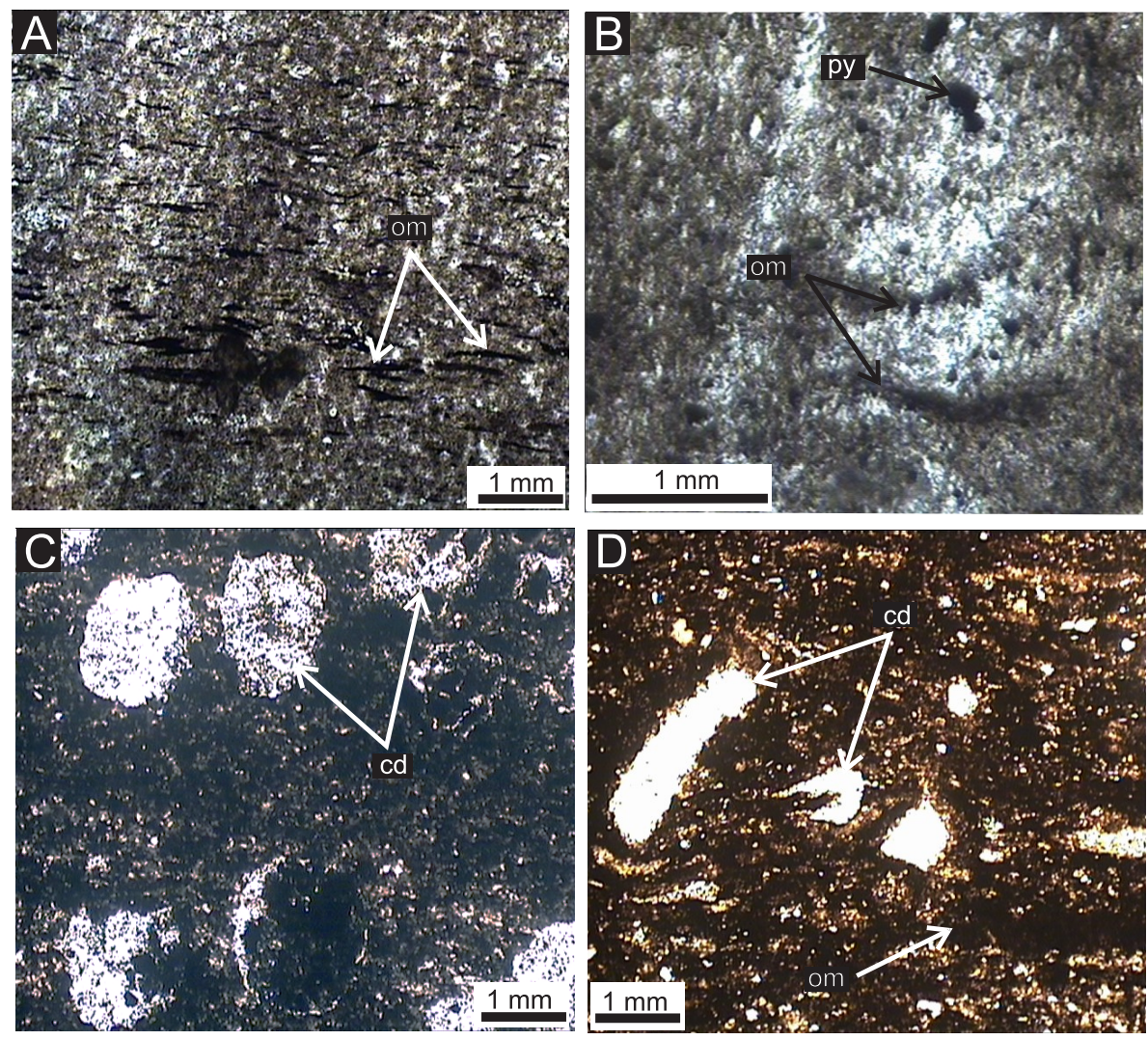

Fig. 7. Photomicrographs of a Silurian rock of open shelf facies (Volyn-Podillyan Plate)

A, B - limy argillite with sub-parallel streaks of organic matter (om) and small pyrite grains (py) from the Krekhiv-1 borehole, depth interval 4 146-4 $151 \mathrm{~m}$; C, D - dark grey marlstones, clayey, pyritized, dolomitized, with organic matter (om) and problematic bioclasts (cd) 


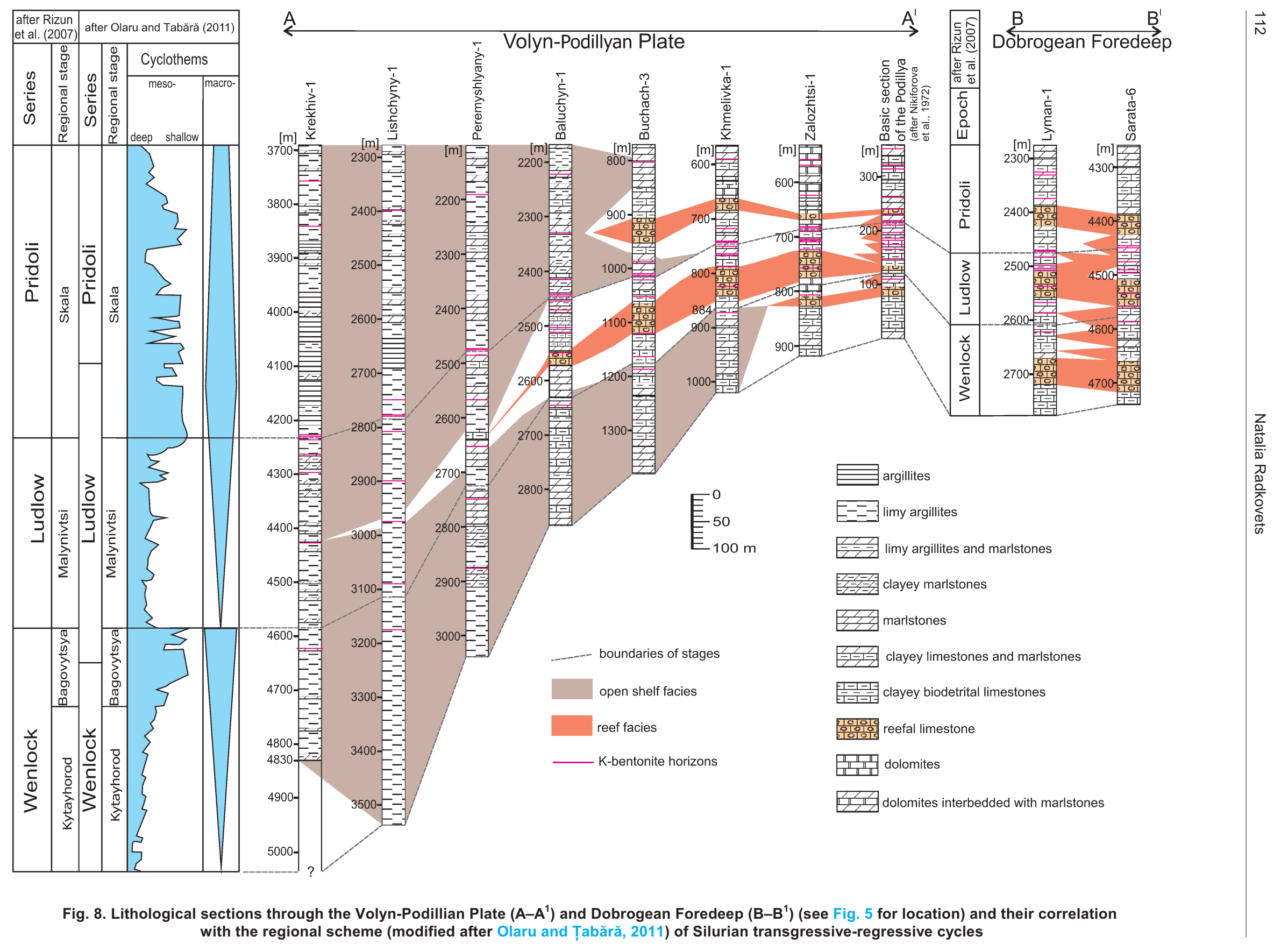




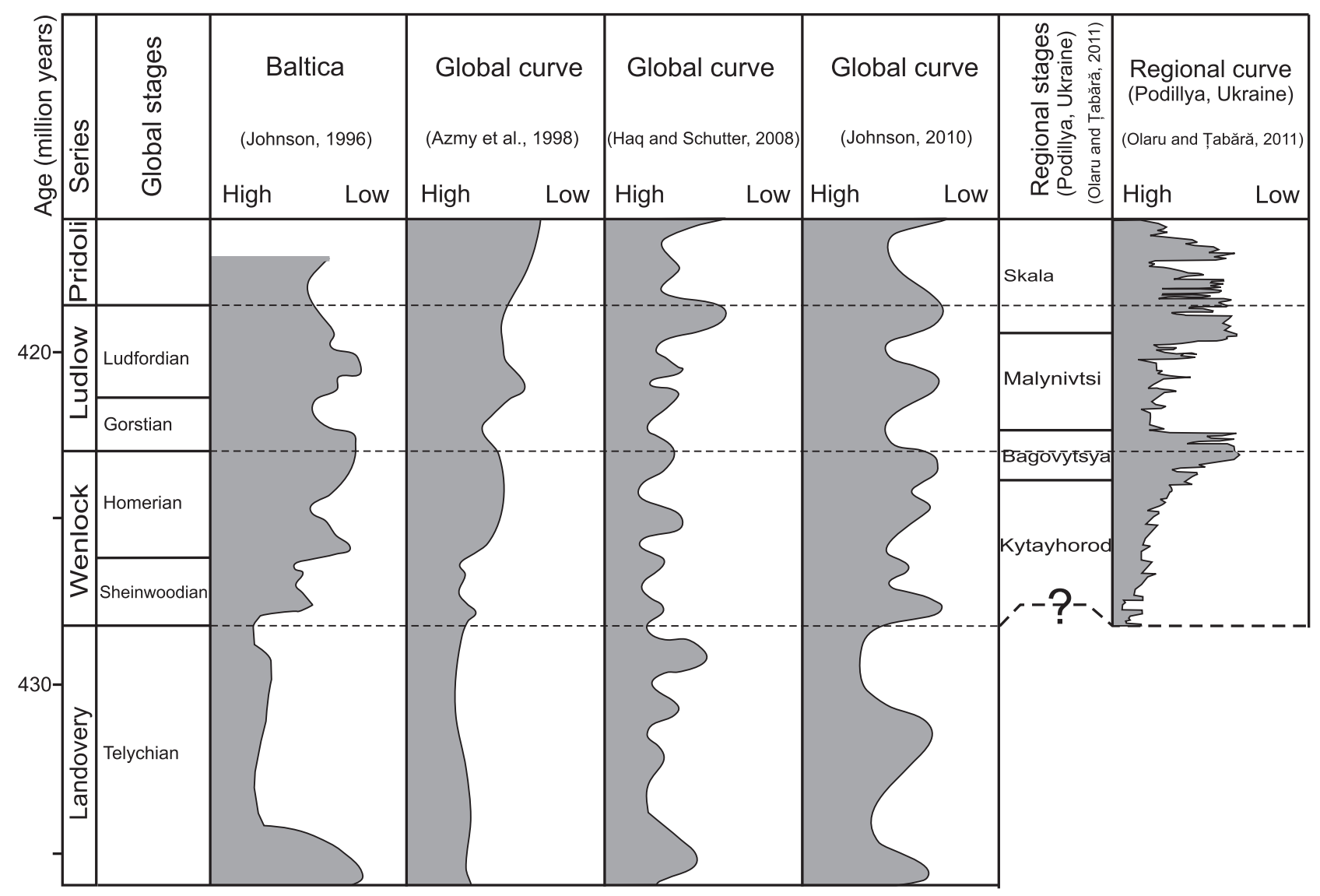

Fig. 9. Compilation of sea level reconstructions for the Silurian

Lyman-1

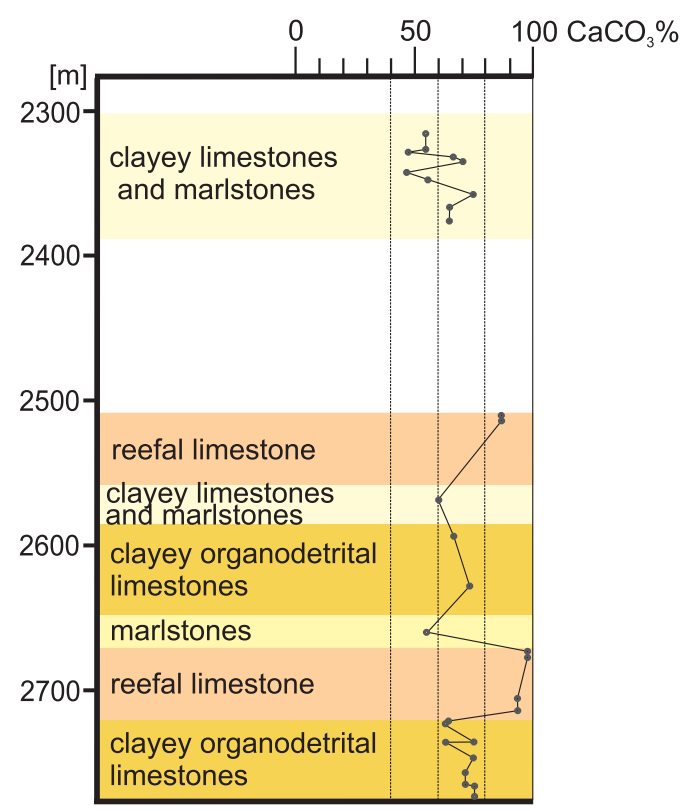

\section{Sarata-6}

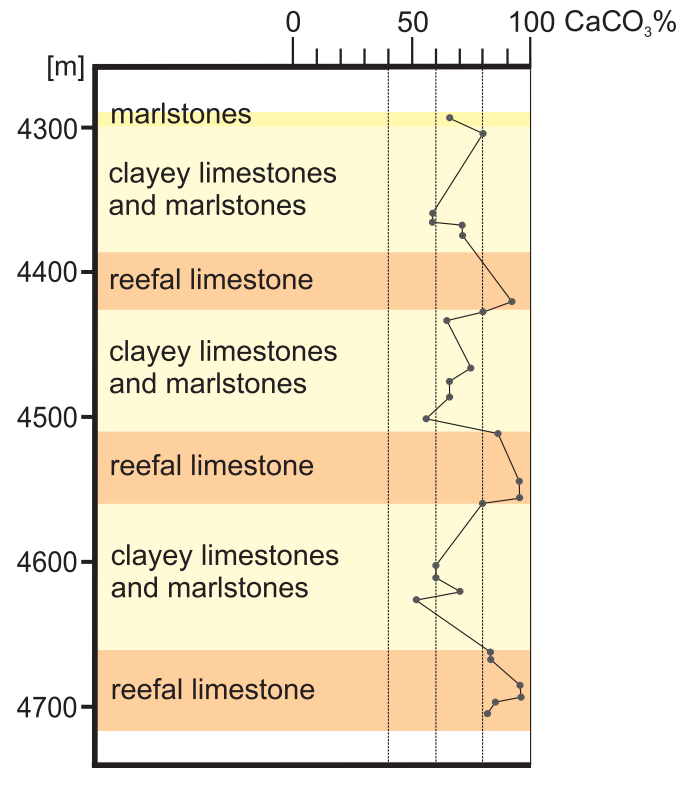

Fig. 10. $\mathrm{CaCO}_{3}$ content in the Silurian sequence of the Lyman-1 and Sarata-6 boreholes (Dobrogean Foredeep) 
and Zalozhtsi-1 boreholes show the occurrence of reef limestones in the Lower and Middle Pridolian strata, the extent of which correlates with short-term regression cycles. There are no reef limestones in the Upper Pridoli strata, which reflects the cessation of reef building (cf. Verniers et al., 2008).

Based on the typical lithological sections (Fig. 8) and sequences in a number of boreholes from the Volyn-Podillyan Plate and Dobrogean Foredeep as well as from Moldova and Romania (Lodan, 1999; Olaru et al., 2006; Olaru and Tabără, 2011), it can be concluded that the reef limestones developed from the Wenlock to Middle Pridoli. This stratigraphic interval is a time of continual reef formation. As to the spatial extent of reef constructions, their limits during the above-mentioned time interval were shifting, depending on the shoreline fluctuations caused by transgressive-regressive cycles. Consequently, a migrating reef facies was formed during the Silurian (Wenlock-Middle Pridoli).

\section{FACIES PATTERN IN RELATION TO SILURIAN OCEANOGRAPHY AND SEA LEVEL CHANGES}

\section{GLOBAL AND REGIONAL EVENTS}

At the end of Ordovician time, a global regression took place due to a significant fall of temperature and glaciation in the southern hemisphere, when the ice cap covered the central part of Gondwana. As a result, the southern shelf of the Baltica sedimentary basin (southwestern margin of the East European Platform) emerged above the sea level (Verniers et al., 2008) and the area underwent intense erosion.

As it was shown by Royer (2006) and Verniers et al. (2008), the Silurian was an environmentally and faunally stable period in the Earth history - a greenhouse period with a moderate latitudinal climate gradient and impoverished marine faunas slowly recovering from the end-Ordovician mass extinction. However, according to Bickert et al. (1997), Page et al. (2007), Cramer and Saltzman (2007) and Calner (2008), the Silurian period was a time interval of repeated global changes. Marine biodiversity crises took place, affecting e.g., graptolites, conodonts, chitinozoans, acritarchs, brachiopods and reefs, and these turnovers were closely linked to abrupt and significant changes in oceanography and the global carbon cycle. Based on observed temporal changes in lithology and conodont faunas in the carbonate platform rocks of Gotland, three main events - the Early Silurian Ireviken Event, the Middle Silurian Mulde Event, and the Late SiIurian Lau Event - have been identified (Jeppsson, 1990) with regard to biodiversity changes and relation to carbon and oxygen stable isotope evolution and sea level change. For the sedimentary succession of Podillya, Ukraine, temporal changes in isotope composition $\left(\delta^{13} \mathrm{C}, \delta^{18} \mathrm{O}\right)$ and faunas have been established (Racki et al., 2012), which are related to the regional carbonate crisis and cooling episodes, corresponding to the Ireviken and Klonk events.

A significant transgression started at the beginning of the Silurian (Early Llandovery) advancing from the west and northwest (the present-day territory of Estonia, Latvia and Lithuania). A sedimentary basin developed, in which organic-rich muds accumulated (Nestor and Einasto, 1977; Einasto et al., 1986). Further transgression eastwards (Late Llandovery-Early Wenlock) resulted in submerging of significant territories of the western margin of Baltica and the sedimentary basin had reached the shape and size, which it had during the Ordovician (Verniers et al., 2008). The Silurian southern shelf basin of Baltica was located in low southern latitudes (15-20 ${ }^{\circ} \mathrm{S}$ ) (Fig. 11A; Torsvik et al., 1996). In the Early Wenlock, a stable sedimentary basin was formed and the facies zoning was ultimately established there from the shoreline towards the shelf break: lagoonal, reef and open-shelf facies.

Figure 11B shows the model of southern shelf of Baltica for mid-Silurian times. Location of the three above-mentioned facies is indicated in the map for Ludlow time. In this epoch, the reef formation reached its maximum development and the reef constructions occupied the greatest area. As it is shown in the map, the lagoonal facies was separated from the open sea by a barrier reef belt that stretched along the entire shelf. Beyond the reef belt in the deeper part of the basin, organic-rich sediments of the open-shelf facies were deposited.

The results of my lithological investigations of the Ukrainian part of the Silurian area are consistent with the oceanic-climatic model by Bickert et al. (1997), showing the expansion of the oxygen minimum zone towards the shore during transgressions and its significant retreat towards the shelf break during regressions. Transgressive-regressive cycles could correlate with the climatic changes (Page et al., 2007; Cramer and Saltzman, 2007; Calner, 2008) and the latter could represent the important factor of biodiversity crises. However, our data show that the impact of these climatic changes on carbonate sedimentation was not that considerable and the reef building, though changing its spatial extent, might have not been interrupted during the Wenlock-Middle Pridoli. Nikiforova et al. (1972) described reef-building organisms as well as bioherms within the entire succession in numerous outcrops of Silurian shallow-water shelf deposits of Podillya. Another evidence of favourable climatic environments is a permanent existence of reefs in sections of Western Lithuania (Lazauskiene et al., 2003; Zdanaviciute and Lazauskiene, 2007) in the time range from Late Wenlock to Early Pridoli.

The existing data allow assuming that, though the climatic changes during the Silurian had a significant control on distribution of carbonate fauna within the southern shelf of Baltica, the environments in these subequatorial latitudes still remained favourable for persistent existence of reefal buildups.

\section{DEPOSITIONAL ENVIRONMENTS}

Figure 12 shows the scheme of depositional environments at the southern shelf of Baltica. Within the shallow part of the water column within depths of up to $100 \mathrm{~m}$, where water was oxygenated, the calcareous plankton evolved over the entire area.

The realm of calcareous benthos was restricted by bottom depths of up to $100 \mathrm{~m}$. Shelf calcareous biocenosis was represented by large amount and diversity of fauna including: crinoids, stromatoporoids, rugose corals, tabulate corals, algae, ostracods, gastropods, brachiopods, trilobites and graptolites (Nikiforova et al., 1972). At favourable bathymetric environments, the abundant benthic organisms created numerous submarine overgrowths and banks which formed the reef. The deeper part of the shelf with water depth exceeding $100 \mathrm{~m}$ was occupied by the oxygen minimum zone, which caused the phyto- and zooplankton extinction, and partial dissolution of the calcareous skeletal debris, and facilitated the efficient organic matter fossilization and accumulation of organic-rich sediments. Anoxic environment in this deeper part of the basin became a determinant factor for the formation of organic-rich (with the total organic carbon content reaching $>2 \%$ ) so-called graptolitic shales. Deposition of organic-rich sediments of this age was a global phenomenon and resulted from the Silurian oceanic anoxic event (Verniers et al., 2008). 


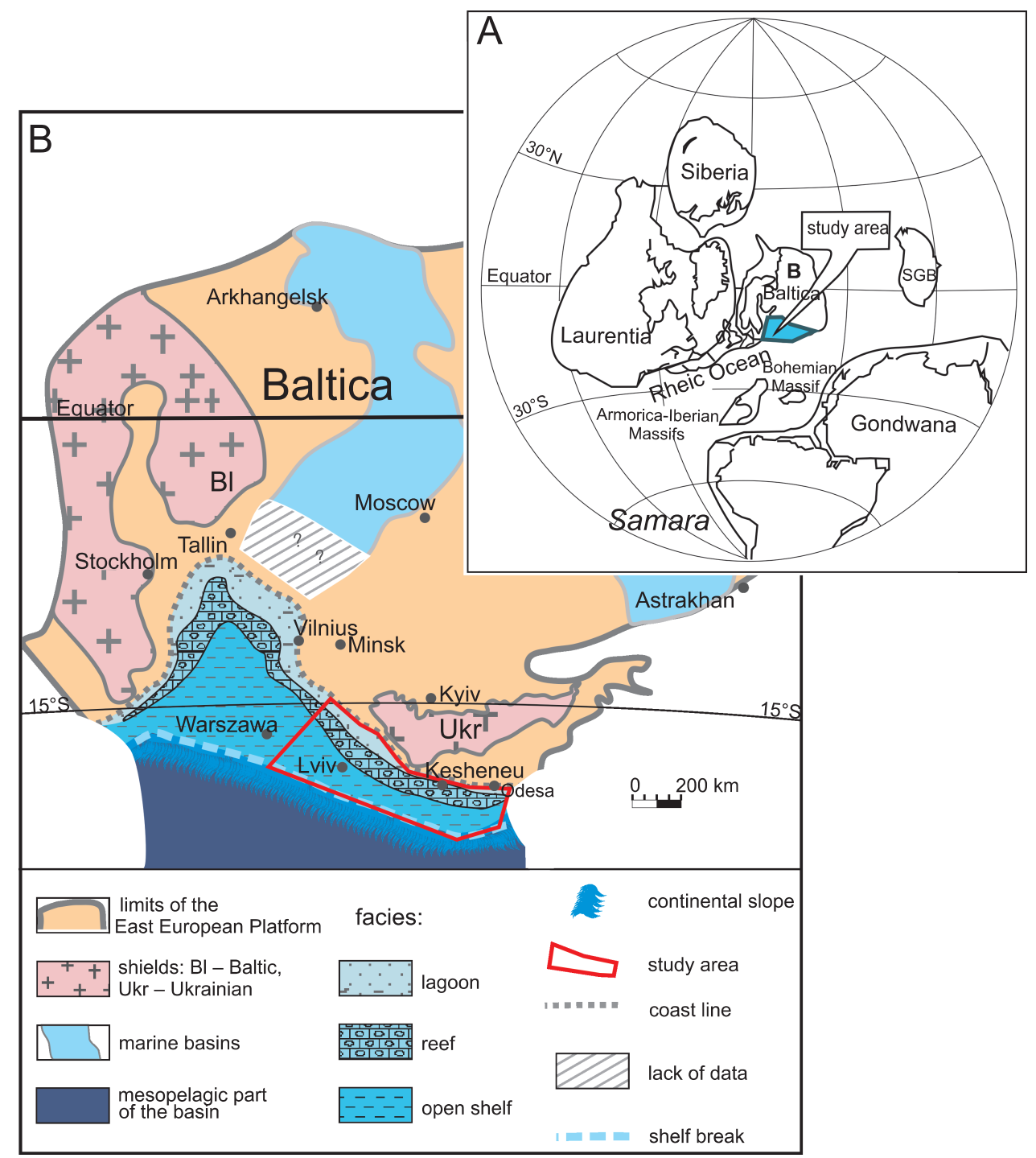

Fig. 11A - palaeogeographic map for mid-Silurian times, showing the position of the study area within Baltica (after Torsvik et al., 1996); B - sketch map showing the model of southern shelf

Figure 8 shows that during the Silurian the regression and transgression cycles controlled the shifts of boundaries of facies, especially of open-shelf and reef ones. During transgressions (Fig. 13A), in this instance in the Wenlock, the open-shelf facies significantly advanced towards the shore. The area of oxygen-minimum zone and, consequently, of organic-rich sediments deposition expanded. The reef formation zone had a minimum width and occurred in the most proximal part of the shelf within the water depth of $100 \mathrm{~m}$. In the periods of regressions, as it was in the Ludlow (Fig. 13B), the reef formation zone extended towards the open sea.

The facies change, in particular the spatial and temporal evolution of reef formation is illustrated in Figure 14. During the regression (Ludlow) the newly formed reefs shifted towards the deeper part of the basin and accumulated upon the fore-reef facies, while the old reefs were covered by the shallow-water back-reef lagoonal sediments. During the transgression (Pridoli) the opposite processes took place. The newly formed reefs covered the back-reef sediments, while the old reefs were overlain by the deeper-water fore-reef deposits. Hence, during the Silurian, the reef-formation zone was shifting towards the shore and back towards the shelf break depending on sea level changes, remaining a continuous phenomenon for the shallow part of the entire southern shelf of Baltica (Fig. 11B).

Analysis of lithological sections on Ukraine and Moldova and the data on the adjacent territories show that the reef belt extended over approximately $2300 \mathrm{~km}$ and its maximum width was about $150 \mathrm{~km}$.

\section{SUMMARY AND CONCLUSIONS}

Study of well-log data, lithological and petrographic investigations of Silurian strata in the Volyn-Podillyan Plate and the Dobrogean Foredeep and their correlation with coeval deposits in the adjacent territories of Moldova and Romania (Moldovian Platform), Poland, Lithuania, Latvia and Estonia allowed us de- 


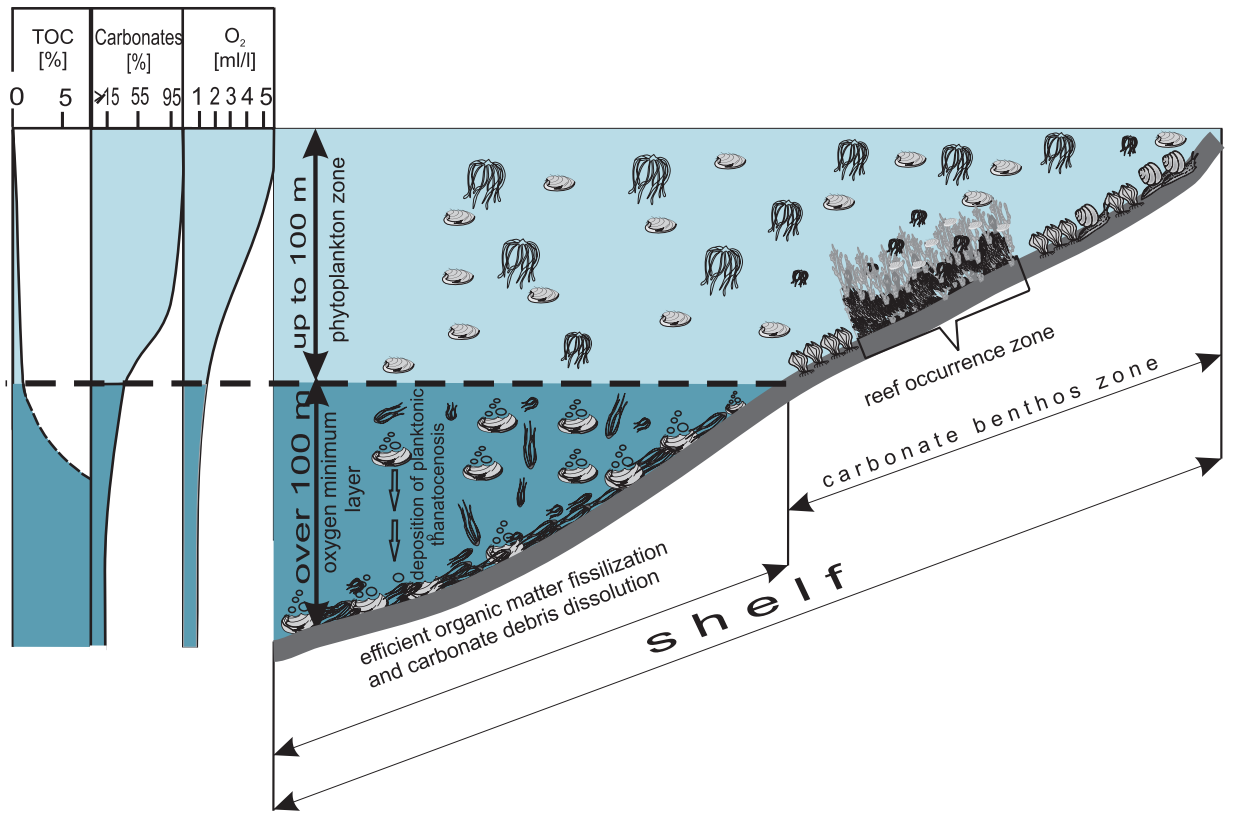

Fig. 12. Scheme of depositional environments in the Silurian within the southern shelf of Baltica

$\mathrm{O}_{2}$ concentration in water column after Demaison and Moore (1980); TOC - Total organic carbon
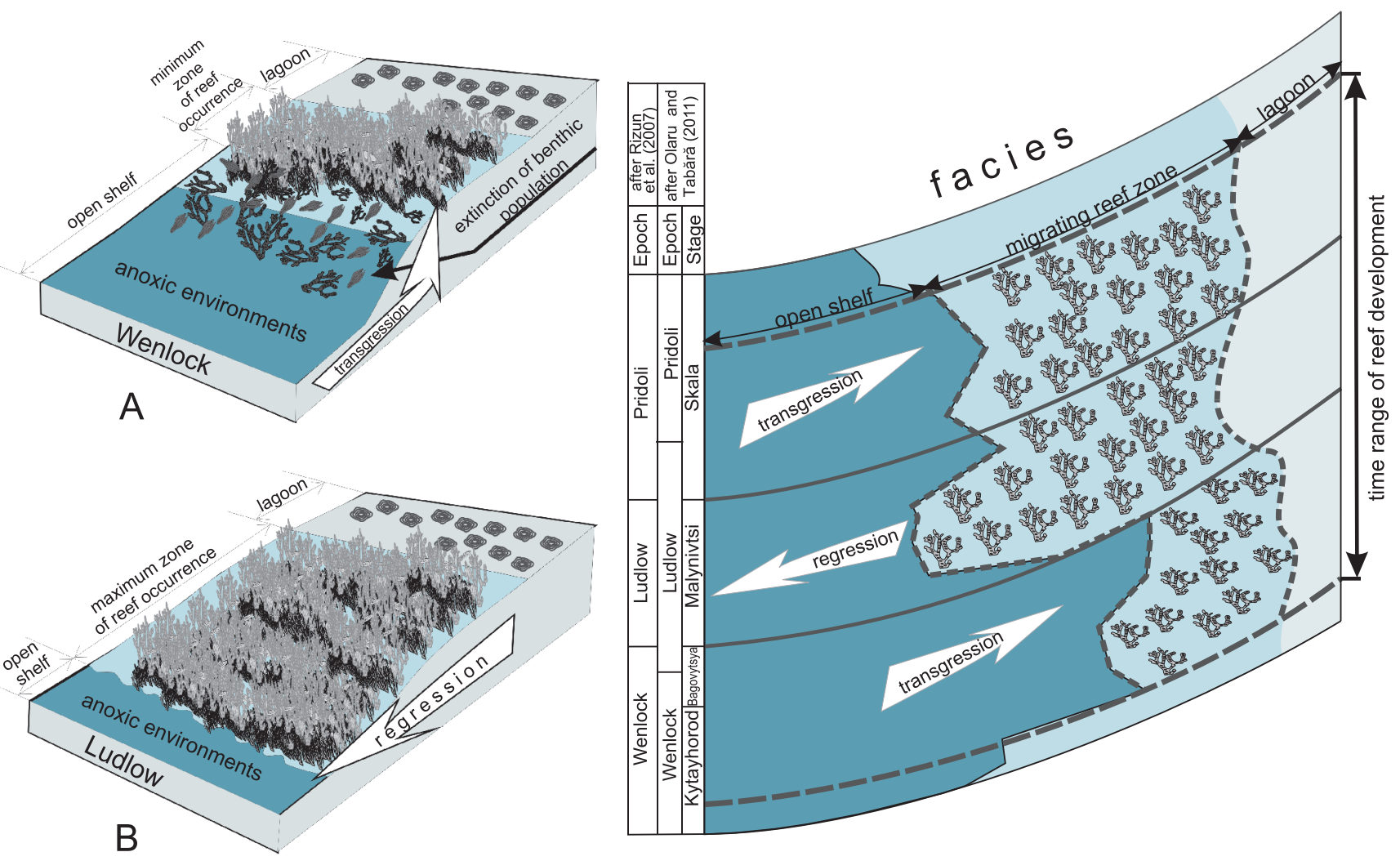

Fig. 13. Models of the southern shelf of Baltica in the Silurian for the periods of transgression $(A)$ and regression (B), which controlled the shifts of the boundary between

Fig. 14. Spatial and temporal evolution of migrating reef facies in the Silurian within the southern shelf of Baltica 
veloping an integral concept of the extent of Silurian deposits, regularities of thickness changes, petrographic composition of rocks and distribution of lagoonal, reef and open shelf facies within the southwestern margin of the East European Platform. The reef facies, which represented a barrier between the lagoonal and open shelf facies, was a subject of a number of earlier investigations, which considered separate Silurian reef constructions in different parts of the south-western margin of the East European Platform. In this study, reconstruction of sedimentary environments during the Silurian within the southern shelf of Baltica integrates my results and the data from the publications of earlier authors. It shows that there was a continuous reef belt stretching along the entire shelf within the time range from Wenlock to Middle Pridoli. The reef facies was shifting within the shelf and changing its width depending on sea level changes. Analysis of palaeoceanographic environments of the reef formation shows that the oxygen minimum layer, which in Silurian marine basins occupied the water column below a depth of $100 \mathrm{~m}$, and the transgressive-regressive cycles were the decisive factors of spatial and temporal distribution of facies in the sedimentary basin of the southern shelf of Baltica. Organic-rich anoxic sediments were being deposited in the deeper part of the basin, while the shallower part was the area of reef buildups and back-reef lagoonal sediments. The boundary between the open-shelf and the reef facies was controlled by the top of the oxygen minimum layer, which was shifting towards the open sea or back towards the shore depending on changing depth of the shelf in different time intervals of the Silurian. Both the reef and the open-shelf facies are prospective for hydrocarbons and hence the delineation of the areas of their occurrence in different time ranges of the Silurian is important for exploration purposes.

Acknowledgements. The author is grateful to all reviewers: G. Tari (Vienna, Austria), Y. Koltun (Lviv, Ukraine) and an anonymous reviewer for many helpful comments on an earlier version of this manuscript. K. Grygorchuk, V. Gnidets and D. Machalskyi (Lviv, Ukraine) are thanked for providing access to the data.

\section{REFERENCES}

Azmy, K., Veizer, J., Bassett, M.G., Copper, P., 1998. Oxygen and carbon isotopic composition of Silurian brachiopods: implications for coeval seawater and glaciations. GSA Bulletin, 110: $1499-1512$

Bickert, T., Pätzold, J., Samtleben, C., Munnecke, A., 1997. Palaeoenvironmental changes in the Silurian indicated by stable isotopes in brachiopod shells from Gotland, Sweden. Geochemica et Cosmochimica Acta, 61: 2717-2730.

Calner, M., 2008. Silurian global events - at the tipping point of climate change. In: Mass Extinction (ed. M.T.E. Ashraf): 21-57. Springer.

Chebanenko, I.I., Vishsnyakov, I.B., Vlasov, B.I., 1990. Geotektonika Volyno-Podolii (in Russian). Naukova Dumka, Kiev.

Chyzh, E.I., 1977. Izucheniye iskopayemykh organogennykh postroyek silura Volyno-Podolii (in Russian). Geologicheskiy Zhurnal, 37: 101-108.

Cramer, B.D., Saltzman, M.R., 2007. Fluctuations in epeiric sea carbonate production during Silurian positive carbon isotope excursions: a review of proposed paleoceanographic models. Palaeogeography, Palaeoclimatology, Palaeoecology, 245: 37-45.

Demaison, G.J., Moore, J.T., 1980. Anoxic environments and oil source bed genesis. AAPG Bulletin, 60: 1179-1209.

Drygant, D.M., 2000. Lower and Middle Paleozoic of the VolynPodillyan margin of the East-European Platform and Carpathian Foredeep (in Ukrainian with English abstract). Naukovi zapysky Derzhavnoho pryrodoznavchoho muzeyu, 15: 24-87.

Drygant, D.M., Gavrylyshyn, V.I, Gynda, V.A., 1982. Verkhniy dokembriy-nizhniy paleozoy Srednego Pridnestrovya (in Russian). Naukova Dumka, Kiev.

Einasto, R.Z., Abushik, A.F., Kaljo, D.P., Koren, T.N. Modzalevskaya, T.L., Nestor, H.Z., 1986. Silurian sedimentation and the fauna of the East Baltic and Podolian marginal basins: a comparison. In: Theory and Practice of Ecostratigraphy (eds. D. Kaljo and E. Klaamann): 65-72. Academy of Sciences of the Estonian SSR, Tallinn.

Folk, R.L., 1962. Spectral subdivision of limestone types. AAPG Memoir, 1: 62-84.

Gerasimov, M.Y., Bondarchuk, G.K., Skoryk, A.M., Koltsov, S.V., Fedorchuk, V.F., Dyakovich, P.I., 2006. Geodinamika, seysmichnost i neftegazonosnost Chernomorsko-Kaspiyskogo regiona (in Russian). In: Tektonichna karta pivdnya Ukrainy z pozytsiy aktualistychnoi geodynamiky. Sbornik dokladov VI Mezhdunarodnoy konferentsii “Krym-2005”, Simferopol: 11-40.

Gnidets, V.P., Grigorchuk, K.G., Polukhtovych, B.M., Fedyshyn, V.O., 2002. Lithogenesis of Devonian Deposits of Dobrogea Foredeep (Palaeooceanography, Sedimentary Cyclicity, Reservoir Rocks' Formation) (in Ukrainian with English abstract). UkrDGRI, Lviv.

Haq, B.U., Schutter, S.R., 2008. A chronology of Paleozoic sea-level changes. Science, 322: 64-68.

Histon, K., Klein, P., Schönlaub, H.P., Huff, W.D., 2007. Lower Palaeozoic K-bentonites from the Carnic Alps, Austria. Austrian Journal of Earth Sciences, 100: 26-42.

Huff, W.D., Bergström, S.M., Kolata, D.R., 2000. Silurian K-bentonites of the Dnestr Basin, Podolia, Ukraine. Journal of the Geological Society, 157: 493-504.

Jarochowska, E., Kozłowski, W., 2014. Facies development and sequence stratigraphy of the Ludfordian (Upper Silurian) deposits in the Zbruch River Valley, Podolia, western Ukraine: local facies overprint on the $\delta^{13} \mathrm{C}_{\text {carb }}$ record of a global stable carbon isotope excursion. Facies, 60: 347-369.

Jeppsson, L., 1990. An oceanic model for lithological and faunal changes tested on the Silurian record. Journal of the Geological Society, 147: 663-674.

Johnson, M.E., 1996. Stable cratonic sequences and a standard for Silurian eustasy. GSA Special Paper, 306: 203-211.

Johnson, M.E., 2010. Tracking Silurian eustasy: alignment of empirical evidence or pursuit of deductive reasoning? Palaeogeography, Palaeoclimatology, Palaeoecology, 296: 276-284.

Kaljo, D., Martma, T., Grytsenko, V., Brazauskas, A., Kaminskas, D., 2012. Prídolí carbon isotope trend and upper Silurian to lowermost Devonian chemostratigraphy based on sections in Podolia (Ukraine) and the East Baltic area. Estonian Journal of Earth Sciences, 61: 162-180.

Krandiyevsky, V.S., Ischenko, T.A., Kiryanov, V.V., 1968. Paleontologiya i stratigrafiya nizhnego paleozoya VolynoPodolii (in Russian). Naukova Dumka, Kiev.

Kruglov, Ń.Ń., Tsypko, A.K., 1988. Tektonika Ukrainy (in Russian). Nedra, Moscow.

Kurovets, I.M., Drygant, D.M., Chepil, P.M., Chepusenko, P.S. 2010. Geologo-petrofizychna kharakterystyka baseynovykh dribnozernystykh porid syluru pivdenno-zakhidnoyi okrayiny Skhidnoyevropeyskoi platform (in Ukrainian). Zbirnyk materialiv 
mizhnarodnoyi konferentsiyi "Suchasni problemy litologiyi osadovykh baseyniv Ukrainy i sumizhnykh terytoriy", Kyiv.

Kurovets, I., Drygant, D., Naumko, I., Kurovets, S., Koltun, Y., 2012. Geological and physical-chemical characteristics of Lower Paleozoic deposits of Volyno-Podillya, Western Ukraine. Biuletyn Państwowego Instytutu Geologicznego, 449: 119-130.

Lazauskiene, J., Sliaupa, S., Musteikis, P., Brazauskas, A., 2003. Sequence stratigraphy of the Baltic Silurian succession: tectonic control on the foreland infill. Geological Society Special Publications, 208: 95-115.

Lodan, M., 1999. The Palaeozoic brachiopods of Romania. GeoEco-Marina, 4: 135-145.

Łuczyński, P., Skompski, S., Kozłowski, W., 2009. Sedimentary history of Upper Silurian biostromes of Podolia (Ukraine) based on stromatoporoid morphometry. Palaeogeography, Palaeoclimatology, Palaeoecology, 271: 225-239.

Mõtusa, M-A., Grytsenko, V., 2007. Morphological variation of the tabulate coral Paleofavosites cf. collatatus Klaamann, 1961 from the Silurian of the Bagovichka River localities, Podolia (Ukraine). Estonian Journal of Earth Sciences, 56: 143-156.

Nestor, H.E., Einasto, R.E., 1977. Fatsialno-sedimentologicheskaya model siluriyskogo paleobaltiyskogo perikontinentalnogo basseyna (in Russian). In: Fatsii i fauna silura Pribaltiki. AN ESSR, Tallin: 89-121.

Nikiforova, O.I., Predtechensky, N.N., Abushik, A.F., Ignatovitch, M.M., Modzalevskaya, T.L., Berger, A.Y., Novoselova, L.S., Burkov, Y.K., 1972. Oporny razrez silura i nizhnego devona Podolii (in Russian). Nauka, Leningrad.

Olaru, L., Țabără, D., 2011. Lithological and palynostratigraphical correlations between Silurian deposits from the Dnestr Basin (Podolia) and the North of the Moldavian Platform (Romania). Analele Stiintifice ale Universitatii "Al. I. Cuza" Seria Geologie, 57: 29-47.

Olaru, L., Brânzilă, Ě., Țabără, D., 2006. Geological and palynological contribution to the Silurian from the north of Moldavian platform. Analele Stiintifice ale Universitatii "Al. I. Cuza" Seria Geologie, 52: 67-84

Page, A.A., Zalasiewicz, J.A., Williams, M., Popov, L.E., 2007. Were transgressive black shale a negative feedback modulating glacioeustasy in the Early Palaeozoic icehouse? In: Deep-time Perspective on Climate Change: Marrying the Signal from Computer Models and Biological Proxies (eds. M. Williams, A.M. Haywood, F.J. Gregory and D.N. Schmidt): 123-156. The Micropalaeontological Society, Special Publications. The Geological Society, London.

Podhalańska, T., 2013. Graptolites - stratigraphic tool in the exploration of zones prospective for the occurrence of unconventional hydrocarbon deposits. Przegląd Geologiczny, 61: 621-629.

Poprawa, P., 2010. Shale gas potential of the Lower Palaeozoic complex in the Baltic and Lublin-Podlasie basin (in Polish with English summary). Przegląd Geologiczny, 58: 226-249.

Poprawa, P., Kiersnowski, H., 2008. Potential for shale gas and tight gas in Poland (in Polish with English summary). Biuletyn Państwowego Instytutu Geologicznego, 429: 145-152.

Porębska, E., Kozłowska-Dawidziuk, A., Masiak, M., 2004. The lundgreni event in the Silurian of the East European Platform, Poland. Palaeogeography, Palaeoclimatology, Palaeoecology, 213: 271-294.

Porębski, S.J., Prugar, W., Zacharski, J., 2013. Silurian shales of the East European Platform in Poland - some exploration problems. Przeglad Geologiczny, 61: 630-638.
Racki, G., Baliński, A., Wrona, R., Małkowski, K., Drygant, D., Szaniawski, H., 2012. Faunal dynamics across the Silurian-Devonian positive isotope excursions $\left(\delta^{13} \mathrm{C}, \delta^{18} \mathrm{O}\right)$ in Podolia, Ukraine: comparative analysis of the Ireviken and Klonk events. Acta Palaeontologica Polonica, 57: 795-832.

Rizun, B., Pavlyuk, M., Medvedev, A., Kinakh, M., 2007. Silurian buried reefs of Volyn-Podillya in the context of oil and gas prospectives (in Ukrainian with English abstract). Geologiya i Geokhimiya Goryuchykh Kopalyn, (4): 5-25.

Royer, D.L., 2006. $\mathrm{CO}_{2}$-forced climate thresholds during the Phanerozoic. Geochimica et Cosmochimica Acta, 70: 5665-5675.

Sachsenhofer, R.F., Koltun, Y.V., 2011. Black shales in Ukraine - a review. Marine and Petroleum Geology, 30: 1-12.

Skompski, S., Łuczyński, P., Drygant, D., Kozłowski, W., 2008. High-energy sedimentary events in lagoonal successions of the Upper Silurian of Podolia, Ukraine. Facies, 54: 277-296.

Su, W.B., He, L.Q., Baum, G.R., Huff, W.D., Li, Z.M., 2004. K-Bentonites near the Ordovician-Silurian boundary in South China: contributing factors to the terminal Ordovician multiple-sphere crises? Abstracts volume, 32 International Geological Congress: Florence, Italy.

Tari, G., Poprawa, P., Krzywiec, P., 2012. Silurian lithofacies and paleogeography in Central and Eastern Europe: implications for shale gas exploration. SPE 151606, SPE/EAGE European Unconventional Resources Conference and Exhibition, Vienna, 20-22, 2012.

Tari, G.C., Krzywiec, P., Poprawa, P., Popadyuk, I., Krezsek, C., 2014. Interpretation of the Silurian Basin of Central and Eastern Europe as a pro-foreland flexural basin: implications for shale gas exploration. In: SPE/EAGE European Unconventional Resources Conference and Exhibition. Society of Petroleum Engineers, Vienna, February, 2014.

Torsvik, T.H., Smethurst, M.A., Meert, J.G., Van der Voo, R., McKerrow, W.S., Brasier, M.D., Strut, B.A., Walderhaug, H.J., 1996. Continental break-up and collision in the Neoproterozoic and Palaeozoic: a tale of Baltica and Laurentia. EarthScience Reviews, 40: 229-258.

Tsegelnyuk, P.D., Gritsenko, V.P., Konstantinenko, L.I., Ishchenko, A.A., Abushik, A.F., Bogoyavlenskaya, O.V., Drygant, D.M., Zaika-Novatsky, V.S, Kadlets, N.M., Kiselev, G.N., Sytova, V.A., 1983. The Silurian of Podolia. The Guide to Excursion. International Union of Geological Sciences, Subcommission on Silurian Stratigraphy. Naukova Dumka, Kiev.

Vashchenko, V.O., Turchynova, S.M., Turchynov, I.I., Poliha, G.G., 2007. Derzhavna geologichna karta Ukrainy mashtabu 1:200 000. Karpatska seria. Arkush M-35-XXV (IvanoFrankivsk) (in Ukrainian). UkrDGRI, Kyiv.

Verniers, J., Maletz, J., Kř́žž, J., Žigait, Ž., Paris, F., Schönlaub, H.P., Wrona, R., 2008. Silurian. In: The Geology of Central Europe, 1 (ed. T. McCann): 249-302. Geological Society, London.

Yushkevych, V.I., Sandler, Y.M., Kotyk, V.A., Berzhynskaya, L.F., Pashkovskaya, L.Y., Zavolyansky, B.B., 1982. Siluriyskiye rify Lvovskogo progiba i perspektivy ikh neftegazonoznosti (in Russian). In: Metody poiskov i razvedki pogrebennykh rifov. Nauka, Moscow: 98-101.

Zdanaviciute, O., Lazauskiene, J., 2007. The petroleum potential of the Silurian succession in Lithuania. Journal of Petroleum Geology, 30: 325-337. 